\title{
EDITORIAL
}

\section{In This Issue: Patient Outcomes, the Process of Care, and the Capacity for Innovation}

\author{
Kurt C. Stange, $M D, P b D$, Editor \\ Conflict of interest: Dr Stange serves as Chair of the National Advisory Committee for the Robert Wood Jobnson Foundation's Prescription for Health program. \\ Ann Fam Med 2005;3:290-291. DOI: 10.1370/afm.388.
}

$\mathrm{T}$ his issue features the first population-based longitudinal study showing that prehypertension is independently associated with the risk of major cardiovascular events. ${ }^{1}$ These results give credence to the recently released Seventh Report of the Joint National Commission (JNC 7) on High Blood Pressure recommendations for health behavior change among people with prehypertension. ${ }^{2}$ An editorialist considers this and additional implications of this study. ${ }^{3}$

This issue also features 2 studies of electronic health records. One assesses the effect on patient risk factors. ${ }^{4}$ The other analyzes the challenges of implementing the transition from paper to electronic records. ${ }^{5}$ These studies call attention to the potential of electronic health records but show that they are not a panacea. They point out the need for innovation in primary care. The study by Thomas and colleagues shows how a whole system participatory action research approach can increase organizational capacity for innovation. ${ }^{6}$

Hodgson and colleagues conducted one of the first studies to actively engage the perspectives of patients who frequently attend primary care. ${ }^{7}$ They find that patients' perceptions are at odds with many of the previously published perspectives of physicians and researchers. Frequently attending patients want their family physicians to acknowledge their symptoms and provide reassurance. In a quantitative study of 54,074 primary care patients, Naessens and colleagues conclude that frequent attenders appear to be "overserviced [but] underserved." ${ }^{\prime 8}$ Together, these 2 studies identify opportunities for both interpersonal and systems solutions for this group of patients whose needs do not appear to be met by current approaches.

Beach and colleagues find interesting differential effects of being involved in decision making and being treated with dignity. ${ }^{9}$ Both being treated with dignity and being involved in decision making are associated with patient satisfaction across all racial and ethnic groups. Adherence, however, is associated with being involved in decisions for whites and associated with being treated with dignity for racial/ethnic minorities.

A cross-national study by Tarn et al identifies the importance of trust for Japanese and Japanese American patients. ${ }^{10}$ Further analysis shows that patients who change their physician because of insurance coverage report less trust with their current physician, providing further evidence of the negative effect of discontinuity of care.

In a remarkable qualitative study, Malterud and Hollnagel led physicians in exploring clinical events that exposed their vulnerability to patients. ${ }^{11}$ Physicians identify how personal disclosure may lead to constructive interaction.

The findings of the studies by Hodgson, Beach, Tarn, Malterud, and their colleagues present a tremendous stimulus for self-reflection by clinicians. They challenge us to understand "difficult" patients from the perspective of those patients and their cultural groups. They call for ways of interacting that engage and respect what is meaningful for others, particularly among patients who are different from us. These studies suggest that such approaches are an important part of the answer to current concerns regarding inequality, underuse of proven treatments, and patient dissatisfaction.

In a cross-national comparison of 4 countries with different health care systems, family physicians/general practitioners identify continuity of care as a central factor in their ability to deliver high-quality care to their patients. ${ }^{12}$

The methodology article by Fernald and Duclos shows the importance of a team approach for qualitative research and provides a blueprint for developing 
and nurturing the research team. ${ }^{13}$ With 4 qualitative research articles in this issue, this blueprint provides a chance to consider an underrecognized critical factor in conducting rigorous qualitative research.

An essay by Shields considers a case of fetal demise from the author's perspectives as a clinician, educator, and mother. ${ }^{14}$

A seasoned physician writer reflects on different strategies for finding time to write. ${ }^{15}$ We hope that potential authors will take advantage of the wisdom in this essay, and we invite all readers to participate in the online discussion of all the articles in this issue at http://www.annfammed.org.

This issue is accompanied by a supplement that shares early insights from the Robert Wood Johnson Foundation's Prescription for Health initiative. This project is generating insights into novel strategies for promoting multiple healthy patient behaviors through primary care practices and their community partners. Lessons learned by 16 of the 17 funded practice-based research networks are depicted in brief peer-reviewed articles. ${ }^{16}$ Lessons from overarching analyses across the 17 projects are shared in more in-depth research reports. ${ }^{17-20}$ The lessons in these comprehensive articles were informed by the project's unique independent evaluation unit, which collected and analyzed data on an ongoing basis in cooperation with the participating networks and investigators. We look forward to further discoveries that these investigators will share in subsequent research reports in the Annals and elsewhere, and we anticipate additional findings from the 9 practicebased research networks that are just beginning their work in the second round of this project.

To read or post commentaries in response to this article, see it online at http://www.annfammed.org/cgi/content/full/3/4/290.

\section{References}

1. Liszka HA, Mainous AG, King DE, Everett CJ, Egan BM. Prehypertension and cardiovascular morbidity. Ann Fam Med. 2005;3:294-299.

2. US Department of Health and Human Services. The seventh report of The Joint National Committee on Prevention, Detection, Evaluation and Treatment of High Blood Pressure. NIH Publication No 03-5233. December 2003. Available at: http://www.nhlbi.nih.gov/guidelines/ hypertension/express.pdf.

3. Green LA. Prehypertension, patient outcomes, and the knowledge base of family medicine. Ann Fam Med. 2005;3:292-293.
4. O'Connor PJ, Crain AL, Rush WA, Sperl-Hillen JM, Gutenkauf JJ, Duncan JE. Impact of an electronic medical record on diabetes quality of care. Ann Fam Med. 2005;3:300-306.

5. Crosson JC, Stroebel C, Scott JG, Stello B, Crabtree BF. Implementing an electronic medical record in a family medicine practice: communication, decision-making, and conflict. Ann Fam Med. 2005;3:307-311.

6. Thomas P, MCDonnell J, McCulloch J, While A, Bosanquet N, Ferlie E. Increasing capacity for innovation in bureaucratic primary care organizations - a whole system participatory action research project. Ann Fam Med. 2005;3:312-317.

7. Hodgson P, Dowrick C, Smith P, Brown T. Stories from frequent attenders: a qualitative study in primary care. Ann Fam Med. 2005:3:318-323.

8. Naessens JM, Baird M, van Houten HK, Vanness D, Campbell CR. Predicting persistently high primary care use. Ann Fam Med. 2005:3:324-330.

9. Beach M, Sugarman J, Johnson RL, Arbelaez JJ, Duggan PS, Cooper LA. Do patients treated with dignity report higher satisfaction, adherence, and receipt of preventive care? Ann Fam Med. 2005:3:331-338.

10. Tarn DM, Meredith LS, Kagawa-Singer M, et al. Trust in one's physician: the role of ethnic match, autonomy, acculturation, and religiosity among Japanese and Japanese Americans. Ann Fam Med. 2005;3:339-347.

11. Malterud $\mathrm{K}$, Hollnagel $\mathrm{H}$. The doctor who cried: a qualitative study about the doctor's vulnerability. Ann Fam Med. 2005;3:348-352.

12. Stokes T, Tarrant C, Mainous AG, Schers H, Freeman G, Baker R. Continuity of care: is the personal doctor still important? An internationa survey of general practitioners and family physicians in England $\varepsilon$ Wales, the United States, and the Netherlands. Ann Fam Med. 2005;3:353-359.

13. Fernald DH, Duclos CW. Enhance your team-based qualitative research. Ann Fam Med. 2005;3:360-364.

14. Shields SG. On this day of mothers and sons. Ann Fam Med. 2005;3:367-368.

15. Candib LM. Making time to write? Ann Fam Med. 2005;3:365-366.

16. Robert Wood Johnson Foundation with support from the Agency for Healthcare Research and Quality. Prescription for Health: changing primary care practice to foster healthy behaviors. Ann Fam Med. 2005;3(Suppl 2):S33-S67.

17. Bodenheimer T, Young DM, MacGregor K, Holtrop J. Practice-based research in primary care: facilitator or barrier to practice improvement? Ann Fam Med. 2005;3(Suppl 2):S28-S32.

18. Cohen DJ, Tallia AF, Crabtree BF, Young DM. Implementing health behavior change in primary care: lessons from Prescription for Health. Ann Fam Med. 2005;3(Suppl 2):S12-S19.

19. Cifuentes M, Fernald DH, Green LA, et al. Prescription for Health: changing primary care practice to foster healthy behaviors. Ann Fam Med. 2005;3(Suppl 2):S4-S11.

20. Woolf SH, Glasgow RE, Krist AH, et al. Putting it together: finding success in behavior change through integration of services. Ann Fam Med. 2005;3(Suppl 2):S20-S27. 